\title{
Analyzing English Language Teaching Practices in Burkina Faso: A Sociocultural Perspective
}

\author{
Abdoulaye Zongo ${ }^{1}$, Esther Somé-Guiébré2 \\ ${ }^{1}$ Direction Provincial des Enseignements Postprimaire et Secondaire des Bale, Boromo, Burkina Faso \\ ${ }^{2}$ Ecole Normale Supérieure, Koudougou, Burkina Faso \\ Email: someesther@gmail.com
}

How to cite this paper: Zongo, A., \& Somé-Guiébré, E. (2021). Analyzing English Language Teaching Practices in Burkina Faso: A Sociocultural Perspective. Creative Education, 12, 2687-2699.

https://doi.org/10.4236/ce.2021.1211199

Received: October 1, 2021

Accepted: November 27, 2021

Published: November 30, 2021

Copyright ( 2021 by author(s) and Scientific Research Publishing Inc. This work is licensed under the Creative Commons Attribution International License (CC BY 4.0).

http://creativecommons.org/licenses/by/4.0/

\section{Open Access}

\begin{abstract}
The purpose of this study is to explore English language teaching in English as a foreign language context. It examines teaching practices in Burkina Faso and seeks to understand the extent to which those practices promote or inhibit the development of oral skills. As a French speaking country, Burkina Faso implements compulsory English language teaching in middle and secondary schools. Yet, it seems that students are unable to hold a basic conversation after seven years of taking English classes. The purpose of the study is then to identify the instructional practices that hinder the development of learners' communicative abilities. The data collection approach was qualitative using classroom observations and interviews. The method of data analysis was inductive using thematic units of analysis. The findings suggest that teaching activities are not diversified, speaking activities are rare and teaching methods are teacher-centered with little active collaboration between teachers and their learners and between learners themselves.
\end{abstract}

\section{Keywords}

English as a Foreign Language, Communicative Competence, Teaching Practices, Oral Skills, Interaction, Collaboration

\section{Introduction}

This study investigates the teaching practices that English as a Foreign Language (EFL) teachers utilize to develop their students' oral abilities in Burkina Faso. It analyses teaching practices used by teachers in $4 \mathrm{e}$ classes $\left(3^{\text {rd }}\right.$ year in post-primary level) to reinforce students' communicative competence. The idea of the study came from the observation that the majority of students graduate from high school in Burkina Faso after seven years of English language classes and are una- 
ble to express themselves in English. As a teacher supervisor, one of the authors noticed that English lessons offered little to no chance to develop oral skills. During his class visits, he noted that most of the students remained passive throughout the lessons. Classroom conversations seemed to be dominated by teacher talk with a one-way discussion. The supervisor also noted that some teachers asked students questions and reformulated the answers the learners provided systematically.

The rational for this study is to attract teachers' attention to their teaching practices and have them reflect on the effect of those practices on the development of students' communicative competence. It is very common to hear teachers, parents, and school administrators in Burkina Faso complain about the low performance of their children in English and almost always blame the students for their poor achievements. Although the authors acknowledge that students have their share of responsibility, they deem it important for other stakeholders of education notably teachers of EFL (in the case of this article) to develop an awareness of the role of some teaching practices on the acquisition of English as a foreign language.

Burkina Faso is a landlock Francophone West African country that teaches English as a foreign language in both middle and high school. English is taught as a subject for seven years, five hours a week for the first two years and three hours a week the remaining five years. The EFL teachers are for the most part citizens of the country who graduated from the English department of one of the home universities. Burkina Faso has teachers with different background, those with pre-service teaching and in-service teaching certificates and those with no teaching certificate. There are also cohorts of teachers with college degrees but with no English major.

In light of the diversity of background of teachers, the rational of the study and the problem stated above, it is essential to initiate a conversation about teaching practices and their effects on the development of oral skills. A glimpse at the literature unveiled that teaching practices are central to developing oral skills (Alam, 2013; Al-wossabi, 2016; Toro, Camacho-Minuche, Pinza-Tapia, \& Paredes. 2019).

In light of the observation and the literature, the authors of this article explore how teaching practices affect the development of students' oral skills. The study analyzed the teaching practices of $4 \mathrm{e}$ classes (the equivalent of $9^{\text {th }}$ grade or $3^{\text {rd }}$ year of post-primary school). It explored the extent to which teaching practices encourage students' oral participation in the classroom. The data collection methodology was qualitative, and the analysis took the perspective of sociocultural theory.

\section{Sociocultural Theory}

The sociocultural theory views knowledge as a human product that is socially and culturally constructed (Schwandt, 2003). According to Berger \& Luckmann 
(1991), individuals create meaning through their interactions and environment. Therefore, they also consider learning a social process that does not occur only within an individual. In the same vein, Mitchell \& Myles (2004) view learning as "first social, then individual" (p. 198). This theory of learning takes its roots in Vygotsky's (1978) work. Indeed, Vygotsky states that knowledge is affected by other people and is mediated by community and culture. According to Vygotsky, society plays a vital role in learning; therefore, one cannot pretend to learn out of society. The social environment then appears as a mediator in the learning process.

From a sociocultural perspective, learning is a collaborative process. The collaborative nature of learning assumes that learning is more than the assimilation of new knowledge by learners; it is the process by which learners integrate a knowledge community. The collaborative nature of language learning is essential since learning occurs when students are engaged in classroom activities in which they collaborate, negotiate meaning, and reach an agreement (Bruner, 1996).

Learning entails collaboration and interaction between teachers and students and between students and students. According to Gass and Mackey (2007), interaction assumes learning through exposure to language, production of language, and feedback on that language production. They argue that interaction refers to the conversations in which the learners participate. They sustain that, learners receive information about the incorrectness of their utterances and negative evidence through interactional feedback. As for Long (1996), interaction implies negotiation for meaning, especially that triggers adjustment by the native speakers or more competent interlocutors. It then facilitates acquisition by connecting input, internal learner's capacities, particularly selective attention, and productive output.

The literature on teaching practices examined several issues that could potentially hinder the development of oral skills. Among those issues is teachers' talking time. Walsh (2002) argues that teachers often take up much of the classroom talking time, denying their learners the opportunity to participate interactively. Al-wossabi (2016) similarly argued that a mutual interplay between teachers and learners is essential for second language acquisition and production. For Al-wossabi, "The exchange of roles between speakers and listeners does create a productive context for both learners and teachers while learning and teaching the target language" (p. 2062).

Sakarkaya (2013) suggested pair work and group work as techniques providing opportunities for interaction and improved speaking skills. Although Toro, Camacho-Minuche, Pinza-Tapia \& Paredes (2019) drew a similar conclusion, they also pointed out that their use needs to be frequent to provide more opportunities for oral interaction between learners.

In addition, Fitts \& Bowers (2013) argue that English language learners need opportunities to negotiate meaning with more proficient learners. Al-wossabi (2016) views meaning negotiation as a key to oral skill development. Teachers 
should teach negotiation strategies to learners and expose them to different situations where they can utilize their repertoires to express their ideas. Al-wossabi also revealed that students often lack interactional strategies such as " "pardon me," "I'm sorry, can you repeat that?", "what do you mean?", “can you give me an example of that?" , and discourse markers, such as "well, I think, and $O K$ " that would equip them with minimal tools for self-expression.

\section{Methodology}

\section{Study design and research site}

The data collection methodology for this study is qualitative, which according to (Willig, 2001) is concerned with meaning in context. For Willig, qualitative methodology allows the researcher to examine the "why" and "how" questions, not just the "what", "where" and "when" questions. Creswell (2003) further asserts that qualitative researchers are interested in how people make sense of the world and experience events. Creswell also argues that qualitative research seeks to collect an in-depth insight into human behavior and the causes that direct that behavior.

The study was conducted in post-primary schools in two different regions of Burkina Faso, a West African French-speaking country. The study targeted $4 \mathrm{e}$ classes ( $3^{\text {rd }}$ year in middle school) in both urban and rural areas.

\section{Study participants and data collection methods}

This study primarily targeted teachers. Four teacher participants were concerned, and all received pre-service teacher training. At the time of data collection, they each had at least 5 years of teaching experience. The teachers all majored in English at the oldest and most renowned university of the country. After obtaining their bachelor's degree, they took a national test to be trained as English teachers. Upon admission, they were trained at the local college of education and received their teaching certificates. All the teachers were public school EFL teachers and taught about eighteen hours a week.

The researcher observed one classroom of each of the three teacher participants. Each class included about 70 students both genders included and from a diversity of socioeconomic backgrounds. One of the classrooms included in this study was in rural areas and two in urban areas. The study also associated a group of five students from $3^{\text {rd }}$ year in middle school. The five students interviewed were chosen based on their willingness to be interviewed. They were from the two classrooms observed in urban areas and included two girls and three boys of about 14 and 15 years old.

The methods used to collect the data for this study were class observations, semi-structured and focus group interviews. The researchers observed three teachers for six (6) weeks. Each classroom had three (3) sessions a week, and each session was observed during the 6 weeks. They recorded classroom observation sessions through field notes. The field notes were later transcribed before analysis 
Interviews were another method of data collection. They allowed the researchers to get a better insight into the data collected through lesson observations. Harrell \& Bradley (2009) put that "in seeking a complete response, interviews are most likely to provide the depth of information that might be usefup" (p. 10). The interviews were semi-structured and consisted in asking pre-established questions and probing the answers of the respondents (Gray, 2004). The researchers carried out one interview with each of the three teachers observed. The interviews took place at the end of the six weeks of classroom observations. The researchers also carried out a focus group of five students to get a deeper insight into classroom observations through the perception of learners. The focus group lasted forty-five minutes.

\section{Findings}

The data collected revealed that teachers mainly taught grammar lessons in $4 \mathrm{e}$ classes. All the twelve lessons observed for this study mainly were grammar lessons. That observation was also confirmed by an examination of textbooks that revealed that teachers most commonly taught grammar lessons followed by a few vocabularies and reading comprehension lessons. Teacher Bambara confirmed that observation and pointed out in the interview that he rarely conducted other types of lessons than grammar and sometimes vocabulary.

He reported never conducting speaking lessons and claimed he made his students discuss some topics after reading comprehension. "Similarly, teacher Brou, confessed that he never planned a speaking lesson in $4 \mathrm{e}$ class. However, he sometimes initiated oral activities in his classes. He reported "I have never planned...It comes at random. Any time I tease students, I often say things that are paradoxical or contradictory to bring them to react in English". He went on with justification: "The problem is generally with the three hours, it is very difficult for us ... We have to manage and cover all the areas of the syllabus. We rush up to finish".

This finding from the interviews with the teachers and classroom observation was sustained by the students during focus groups. They all discussed that their English classes were mostly grammar lessons. As one of them pointed out "we mainly study verb tenses, pronouns, possessive adjectives and pronouns, irregular verb, and sometimes vocabulary. We practice or write dialogues." All five participants confirmed this point and regretted not being able to articulate in English.

The activities observed revealed that teachers designed and administered short oral activities with a teacher-students interaction pattern. These interactions involved students in a question-answer pattern with the teacher who fully controlled the talk, and learners had to provide accuracy-based answers. In a grammar lesson entitled 'the past perfect tense' for instance, the teacher assigned the following "listen to the following sentences and turn them into the interrogative form." In another grammar lesson, the oral activity was: Listen to the following sentences and complete with "since" or "for". The activity was individual and the 
students raised their hands to provide their answers.

It appears that the nature of teacher-student interactions observed in the classrooms does not offer learners real opportunities to increase their participation in classroom activities. Achmad \& Yusuf (2014), argued that involving learners in peer interaction is more fruitful and motivating than getting them involved in teacher-student interaction. They state that "students feel comfortable working, interacting and making mistakes with their partners rather than with their teachers and corrective feedback from peers are found to be less daunting than the correction by teachers" (p. 151). This teacher-centered interaction is not likely to bring about effective communication. The authors argue that students are much more ready to interact with each other with more complex responses than with their teachers.

It also appeared from classroom observations and document analysis that teachers rarely organized debates. However, teacher Brou once assigned a homework on the students' opinions on the usefulness of mobile phones as a follow-up of a reading comprehension lesson. The topic of the assignment was: Is it important for a pupil to have a mobile phone? The teacher asked students to deal with the topic individually. During the classroom discussion, teacher Brou called on individual students who read their work. He wrote the best ideas on the board and had the students copy them. As for Mrs. Kassi, she assigned the following discussion topic 'do you prefer life in the village or town? Give your reasons.' She asked the students to work in groups of 5 or 6 to discuss the topic. During the activity, the students primarily discussed in French and then translated their ideas into English. The group activity lasted 15 minutes. Mrs. Kassi then asked the students to report their ideas. The students provided a list of ideas reported on the board: The town is more interesting than village, Electricity - Business centers - peace in village - traditional dance - Village night party, etc.

Mrs. Kassi then wrote students' ideas on the board. There was no interactive discussion between students on the topic or any interactive exchange of contradictory ideas. That activity was the only speaking one observed throughout the process of classroom observation. All the oral activities were focused on grammar lessons and included question-answer interactions.

The interviews with the teachers backed up the absence of a diversity of speaking activities in the classrooms observed. Teacher Bambara declared that he had oral activities when speaking with his students in grammar lessons and said, "when they want to take the floor, I insist they do it in English." He sustained that it is easier to conduct speaking activities in high school grade levels because learners from these levels have already got a substantial grammar background. He also added that time does not allow teachers to cover grammatical aspects of the syllabus and conduct different speaking activities. He claimed that he knows different speaking activities, but he rarely conducts them in $4 \mathrm{e}$ classes because of time constraints. 
Diversifying speaking activities is essential to learner motivation and classroom interaction. Gudu (2015) observes that when teachers do not vary oral activities, it reduces learners' interests and motivation. He also indicates that the students' low oral skills can be explained by the fact that teachers do not integrate various classroom activities in their lessons and hence reduce opportunities for classroom interaction. He further declares that not diversifying speaking activities denies the learners chances of using authentic language context. Alharbi (2015) emphasizes the need to use diverse learner-centered activities to encourage shy students to participate. According to him, "employing various activities and techniques in the classroom also challenges students and caters for diversity in students' learning styles' (p. 109).

The data from classroom observations revealed that students use English to answer their teachers' questions. These answers generally involved learners in accuracy-based oral activities in which they simply needed to provide precise and short responses related to grammatical structures. For instance, teacher Brou gave an exercise with the following instruction: "Turn the sentences into the interrogative form." (Sentence 1. She has been cooking since yesterday. And sentence 2. Madi and his brother have been helping their parents). The students responded orally by inverting the subjects of these sentences. The goal of the exercise was accuracy. In addition to this, the teacher required the students' oral participation in a production exercise. He asked the pupils to make their sentences in the present perfect progressive. The teacher allotted them time to complete the task in their copybooks. Thus, after a moment, the students simply read out their sentences. The only interaction during this assignment consisted of learners following the instruction of the teacher. The assignment did not require any collaboration between the students or between the students and the teachers.

However, when students wanted to ask questions, they generally used French. During Mrs. Kassi's lessons, students sometimes asked questions in French, and the teacher responded in French. For instance, a student asked her: "Madame, to pick, c'est quoi?", and Mrs Kassi replied "On va au jardin pour quoi?” For example, the translation would give: "Madam, what does to pick mean? Mrs. Kassi replied, "Why do we go to the garden?" Mrs. Kassi seems to encourage her students to resort to code-switching in her classes which does not facilitate the development of oral skills (Tuan \& Mai, 2015). Tuan \& Mai sustain learners switch to their mother tongue or L1 when the lesson's topic is difficult. That argument is confirmed when students pointed out hardly understanding classroom activities. One of them stated, "Sometimes, I do not understand what we do in the classroom. Since I cannot speak English, I am obliged to ask the question in French." Another one added, "We are lucky our teacher understands and helps us by explaining and answering our questions in French. Al Hosni (2014) argues that when teachers themselves emphasize using L1 to manage their classrooms, it is likely to encourage learners to use L1 when participating. That argument is confirmed when the teachers argued being aware of the danger of encouraging 
the use of French in class, but as Mrs. Kassi put it, "most of the time, we don't have the choice. If we keep going in English, we will let the students behind."

In an interview with teacher Brou, he stated that his students have grammatical competence because they can build sentences with correct tenses. For him, the learners' participation is satisfactory when he instructs to produce model sentences to illustrate new grammatical structures. Still, they do face challenges using this linguistic competence to communicate effectively. He pointed out learners' weaknesses in using English to communicate: "the learners have the ability in terms of grammar, let us say to form words and sentences. (...) They are very poor in vocabulary. They start a sentence, and they are blocked. This is the problem."

Classroom observations also revealed that teachers often interrupted students in their attempts to express their ideas. When learners misused the language, their teachers reacted by cutting the flow of their speech. For example, in teacher Brou's class, whenever students made a mistake, he interrupted them and repeated the correct form of the language item. As a result, the students often no longer continued to share their ideas. For example, the teacher asked: "How important is it for a pupil to have a mobile phone?” A student started the answer: "it is important (the word important wrongly pronounced) for a pupil to ..." Teacher Brou immediately reacted "we say important (a correct form of English pronunciation). The student repeated the correct pronunciation but did not proceed with her idea. The same observation was made in teacher Bambara's classroom when a learner started this sentence: "My mother had given a stylo ...", then the teacher suddenly yelled, "a pen!" The student stopped and did not complete his sentence. The teacher continued with another student.

The focus group with students revealed that teachers constantly interrupted learners' when they expressed themselves. Teachers' quest for accuracy inhibits the learners' need to engage in genuine and meaningful communicative situations in the classroom. For example, one of the students, Aziz, declared, "our teacher asks us questions and when your answer is wrong, he becomes angry and asks you to stop." Azra, another student, confirmed the regular interruptions of students' speech as follows: "our teacher." listens to us when we speak. As soon as you make an error, he stops and corrects you." As for Fabiola, he added, "Our teacher repeats the correct sentence for us when we speak with errors and he tells us not to repeat the same error next time ..."

The constant interruption of learners demotivates learners and hinders their classroom participation. In addition, it reinforces their passivity and prevents them from developing oral skills.

Another handicap to the development of oral skills emerged from the focus group discussion with students. The students raised the issue of the psychological barrier stemming from the classroom environment. They asserted that they did not feel at ease speaking in the classroom because their classmates usually laughed when they made mistakes. As Badou, one of the students, declared: "the 
biggest problem is that the other pupils make fun of you when you speak English with mistakes ...” Fabiola continued, “... and when they laugh, you cannot continue speaking. For student Razak, “... this is discouraging, and you lose your energy to speak". The teachers confirmed that point and argued that they often sensitize their students and discourage them from making fun of their peers. As Teacher Bambara put it, "it is sometimes difficult to avoid such situations. As teachers, we can always anticipate the reaction of the students.

\section{Discussion}

From a sociocultural point of view, Berger \& Luckmann (1991) observe that individuals create meaning when they interact with each other and with the environment in which they live. As far as language learning is concerned, Bruner (1996) argues that learning is more than assimilating new knowledge by learners.

Bruner's discussion pertains to the finding of this study. Indeed, the study's findings have shown that teachers focus on accuracy-based activities intended to get learners to master grammatical structures. All the twelve lessons observed were grammar focused. This teaching approach does not promote genuine interactions in the classroom since students do not necessarily utilize language to deal with everyday life situations. When learning is based on checking the understanding of grammar rules, students are not given opportunities to engage in meaningful interactions.

Oral skills need to be integrated into all lesson types. Thus, learners can benefit more when teachers design various lessons for language practice in the classroom. Teachers can increase learners' potentials to interact through different lessons such as listening, writing, reading, and speaking. Discussing the role of interaction in the classroom, Hedge (2014) observes, "interaction pushes learners to produce more accurate and appropriate language, which itself provides input for other students" (p. 13). For the author, the quest for interaction explains why contemporary English language teaching practices encourage pair-work and group work. However, the research findings showed that the patterns of conversations in $4 \mathrm{e}$ classes do not prioritize student-student or group interactions. The data from observations and the interviews confirmed that the teacher-student conversation pattern highly dominates classroom interactions.

Consequently, most learners remain quiet and listen to conversations between the teacher and a few of their peers in the classroom. Thus, the learners stock knowledge about the language (with the over-teaching of grammar) instead of practicing it. Learning then becomes individual rather than social, as suggested in sociocultural approaches to language learning (Mitchell \& Myles, 2004). The students are confined in passive receivers because teaching practices do not provide opportunities to involve them in interactions that will push language production and the exposure to a variety of input from their classmates (Gass \& Mackey, 2007).

The findings also revealed that teachers do not vary speaking activities in the 
classroom. They deny learners the opportunities to practice their oral skills in various situations they may encounter in real-life situations. Hedge (2014) rightly puts that "the goal of teaching is to equip students to deal ultimately with the authentic language of the real world, they should be given opportunities to cope with this in the classroom" ( $p$. 67). As the findings highlighted, participation tasks in the classroom are mainly characterized by drawing grammar rules, giving examples to illustrate grammatical structures, reading sentences. What appears from this reality is that learners are not prepared to use the language to address daily life issues in the classroom. Classroom language practice in such situations does not promote learners' autonomy. The students are not provided with contextualized language practice, allowing them to negotiate meaning among themselves and with more proficient learners (Fitts \& Bowers, 2013). According to Al-wossabi (2016), the lack of meaning negotiation is a crucial factor in developing little to no oral skills.

Another aspect of the sociocultural perspective, as discussed by Bruner (1996), is the collaborative nature of learning. According to Bruner, learning takes place when students are engaged in classroom activities in which they collaborate, negotiate meaning, and reach an agreement as a result of that collaboration. It is, however, essential to note that findings have indicated that oral language practice in the classroom highly resides on teacher-student interaction. Teachers rarely designed language practice activities that involve learners in pair or group work. Group work or pair work allows learners to improve their speaking skills through interaction (Sakarkaya, 2013). Not using them in the language classroom denies learners collaborative learning and opportunities for oral production (Toro, Camacho-Minuche, Pinza-Tapia, \& Paredes, 2019).

\section{Suggestions}

\section{Promoting a relaxed learning environment}

The research findings revealed that learners face emotional challenges (such as fear making mistakes, the fear of the teacher's reaction, and mockery from their peers) that hinder their desire to participate in the classroom and lead to the development of affective related issues ( $\mathrm{Du}, 2009)$. Those affective issues can affect second language acquisition through learner motivation, attitude towards learning, anxiety, and communication apprehension (Krashen, 1988).

In this regard, teachers must create a pressure-free environment for classroom practice; that would imply shifting from a teacher-centered teaching with an authoritarian way of teaching to student-centered approach with that promote anxiety free setting (Bilokcuoglu \& Debreli, 2018). Bilokcuoglu \& Debreli suggest humor as a way of relieving the pressure by increasing student motivation and reducing anxiety which in turn will create a more humanistic and authentic learning environment

\section{Diversifying Speaking Activities}

The findings of the study suggest that classroom activities do not include a 
diversity of speaking activities. Diversifying speaking activities in the classroom can be a supplementary incitation to increase learners' involvement in classroom oral activities. Because students are different, they certainly have different needs and interests. Therefore, when teachers diversify speaking activities, they are likely to meet most learners' interests. In a discussion about speaking activities, Becker \& Roos (2016) discuss three levels of language use that are reproductive language use, creative language use, and creative and productive language use. Teachers should refer to those different levels of language use to diversify the teaching activities which would in turn would facilitate interaction and offer more speaking opportunities.

\section{Prompting Learners to expand their Ideas/Arguments}

The findings reveal that the teacher-student conversation pattern is the most dominant interaction pattern in the classroom. It has also been demonstrated through class observations that this interaction is mainly characterized by question-answer, focusing on accuracy-based oral activities. When teachers check the correctness of learners' answers or comprehension of grammar rules, they do not create language practice opportunities. They do not challenge learners to speak out their ideas in a complex way as it happens in real-life situations. As a result, students are not engaged into output production. Although question-answer interactions and accuracy-based activities are necessary, teachers need to go beyond them to create an environment that favor true communication and social interaction in which learners are active participants. They nature of classroom interaction should be largely based on referential questions followed by prompts that would encourage learners for more active participation. Somé-Guiébré (2020) argues that EFL classroom interactions in Burkina Faso are dominated by question-answer and accuracy-based activities which are teacher-controlled activities and on based yes/no questions. The author suggests less teacher control and more referential questions for the promotion of communicative competence.

\section{Conclusion}

This study has attempted to identify instructional hindrances that account for learners' limited involvement in classroom conversations. The ultimate goal was to suggest strategies that could contribute to helping teachers improve teaching practices. Therefore, the researchers relied on direct class observations, interviews with teachers, and focus group interviews with students to collect qualitative data.

The study results showed that EFL teachers in $4 \mathrm{e}$ classes do not vary lesson types. More importantly, the findings have revealed a lack of variety of speaking activities that could give learners a real chance to train themselves more significantly in oral language practice. Furthermore, the findings also emphasized participation obstacles related to a certain number of choices teachers make in the classroom. The results emphasized teacher-centeredness to the detriment of 
learner-centeredness in classroom activities because they still dominate the talk. The study also highlighted teachers' will to bring regular correction by constantly inhibiting learners' endeavor from speaking the language in the classroom despite their limitations.

Connecting the research findings with the sociocultural perspective, the researchers suggested that teachers use strategies to foster language classroom interactions. Teachers need to consider these strategies to help learners reinforce their oral skills through adapted and more involving classroom activities.

Relying on the research findings, the researchers contend that teachers can improve their teaching practices by implementing alternative strategies. It could significantly enable learners to reach maximum involvement in the learning process with more enthusiasm and efficiency.

\section{Conflicts of Interest}

The authors declare no conflicts of interest regarding the publication of this paper.

\section{References}

Achmad, D., \& Yusuf, Y. Q. (2014). Observing Pair-Work in an English Speaking Class. International Journal of Instruction, 7, 151-164.

Al Hosni, S. (2014). Speaking Difficulties Encountered by Young EFL Learners. International Journal on Studies in English Language and Literature, 2, 22-30.

Alam, Q. (2013). Improving English Oral Communication Skills of Pakistani Public School Students. International Journal of English Language Teaching, 1, 17-36.

Alharbi, A. H. (2015). Improving Students' English Speaking Proficiency in Saudi Public Schools. International Journal of Instruction, 8, 105-116. https://doi.org/10.12973/iji.2015.818a

Al-wossabi, S. (2016). SLA Classroom Research and EFL Teaching Practices of Oral Skills. Theory and Practice in Language Studies, 6, 2061-2067.

https://doi.org/10.17507/tpls.0611.01

Becker, C., \& Roos, J. (2016). An Approach to Creative Speaking Activities in the young Learners' Classroom. Education Inquiry, 7, Article ID: 27613.

https://doi.org/10.3402/edui.v7.27613

Berger, P., \& Luckmann, T. (1991). The Social Construction of Reality. Penguin

Bilokcuoglu, H., \& Debreli, E. (2018). Use of Humour in Language Classes: An Effective 'Filter' or Affective Filter? Journal of Language and Linguistic Studies, 14, 347-359.

Bruner, J. (1996). The Culture of Education. Harvard University Press.

Creswell, J. W. (2003). Research Design: Qualitative and Mixed Method Approach (2nd ed.). Sage Publications.

Du, X. (2009). The Affective Filter in Second Language Teaching. Asian Social Science, 5, 162-165. https://doi.org/10.5539/ass.v5n8p162

Fitts, S., \& Browers, E. (2013). Developing Academic English with English Language Learners. In M. Beatriz Arias, \& C. J. Faltis (Eds.), Academic Language in Second Language Learning (pp. 33-57). Information Age Publishing Inc.

Gass, S. M., \& Mackey, A. (2007). Input, Interaction, and Output in Second Language 
Acquisition. In B. Van Patten, \& J. Williams (Ed.). Theories in Second Language Acquisition: An Introduction (pp. 170-199). Routledge.

Gray, D. E. (2004). Doing Research in the Real World. SAGE Publications.

Gudu, O. B. (2015). Teaching Speaking Skills in English Language Using Classroom Activities in Secondary School Level in Elderet Municipality, Kenya. Journal of Education and Practice, 6, 55-63.

Harrell, M. C., \& Bradley, M. A. (2009). Data Collection Methods: Semi-Structured Interviews and Focus Group. National Defense Research Institute.

Hedge, T. (2014). Teaching and Learning in the Language Classroom. Oxford University Press.

Krashen, S. D. (1988). Second Language Acquisition and Second Language Learning. Prentice-Hall International.

Long, M. H. (1996). The Role of the Linguistic Environment in Second Language Acquisition. In W. Ritchie, \& T. K. Bathia (Eds.) Handbook of Second Language Acquisition (pp. 413-468). Academy Press.

Mitchell, \& Myles. (2004). Second Language Learning Theories (2nd ed.). Holder Education.

Sakarkaya, V. (2013). Pair and Group Work Activities: Keep Them or Leave Them? In K. Dikilitaş, R. Smith, \& W. Trotman (Eds.), Teacher-Researchers in Action (pp. 163-174). IATEFL Research Special Interest Group.

Schwandt, T. A. (2003). Three Epistemological Stances for Qualitative Inquiry: Interpretation, Hermeneutics, and Social Constructivism. In N. Denzen, \& Y. S. Lincoln (Eds.), The Landscape of Qualitative Research: Theories and Issues (pp. 291-331). Sage Publications.

Somé-Guiébré, E. (2020). Foreign Language Classroom Interaction: Does It Promote Communicative Skills? International Journal of Educational Methodology, 6, 497-505. https://doi.org/10.12973/ijem.6.3.497

Toro, V., Camcho-Minuche, G., Pinza-Tapia, E. \& Paredes, F. (2019). The Use of the Communicative Language Tototeaching Approach to Improve Students' Oral Skills. English Language Teaching, 12, 110-118. https://doi.org/10.5539/elt.v12n1p110

Tuan, N. H., \& Mai, T. N. (2015). Factors Affecting Students' Speaking Performance at Le Thanh High School. Asian Journal of Educational Research, 3, 8-23.

Vygotsky, L. (1978). Mind in Society: The Development of Higher Psychological Process. M. Cole, V. John-Steiner, S. Scribner, \& E. Souberman (Eds.), Havard University Press.

Walsh, S. (2002). Construction or Obstruction: Teacher Talk and Learner Involvement in the EFL Classroom. Language Teaching Research, 6, 3-23.

https://doi.org/10.1191/13621688021r095oa

Willig, C. (2001). Introducing Qualitative Research in Psychology. Open University Press. 